\title{
Genetic divergence and geneflow in three populations of N otopterus notopterus (Pallas, 1769), Madhya Pradesh
}

\author{
Garg RK ${ }^{1}$, Dhanaxi Chaturvedi ${ }^{2}$, Batav N ${ }^{1}$, R. Sharma ${ }^{1}$ and Singh RK ${ }^{1}$ \\ ${ }^{1}$ M.P. Council of Science and Technology (MPCST), Vigyan Bhawan, Nehru Nagar, Bhopal-462003 (M.P.), India. \\ ${ }^{2}$ Boston College for Professional Studies, Jiwaji University, Gwalior-474011, (M.P.), India.
}

\author{
ARTICLE INFO \\ Article history: \\ Received on: 24/04/2014 \\ Revised on: 03/06/2014 \\ Accepted on: 23/07/2014 \\ Available online: $27 / 08 / 2014$ \\ Key words: \\ Notopterus notopterus, \\ RAPD, Gene diversity (h), \\ gene flow $\left(\mathrm{N}_{\mathrm{m}}\right)$, \\ heterozygosity $\left(\mathrm{H}_{\mathrm{S}}, \mathrm{H}_{\mathrm{T}}\right)$, \\ relative differentiation $\left(\mathrm{G}_{\mathrm{ST}}\right)$ \\ polymorphism, \\ conservation.
}

\begin{abstract}
Random amplified polymorphic DNA (RAPD) analysis has been used to elucidate genetic diversity among and within three populations of Notopterus notopterus (Pallas, 1769) of Madhya Pradesh. Genetic differentiation $\left(\mathrm{G}_{\mathrm{ST}}\right)$ among the populations was found to be $\mathrm{G}_{\mathrm{ST}}=0.2380$, estimated gene flow between population $\left(\mathrm{N}_{\mathrm{m}}=1.6010\right)$, intra-population heterozygosity $\left(\mathrm{H}_{\mathrm{S}}=0.2457 \pm 0.0069\right)$ and total heterozygosity $\left(\mathrm{H}_{\mathrm{T}}=\right.$ $0.3225 \pm 0.00133$ ) clearly reflecting high genetic polymorphism. However, population wise, the genetic analyses in Tighra reservoir indicated lower genetic polymorphism $(P)$ as $72.94 \%$ as compared to rest of two populations. Nei's gene diversity (h) was observed as $0.2602 \pm 0.1514$ in Upper Lake, $0.2464 \pm 0.1105$ in Lower Lake and $0.2305 \pm 0.1705$ in Tighra reservoir reflecting much higher gene diversity in Upper Lake population. A phylogenetic relation grouped 16 genotypes of three populations into three clusters which were in agreement with the each population. Current investigation depicted that, as compared to Upper Lake and Lower Lake fish populations, a genetic changes including reduced genetic diversity and significant differentiation have taken place in Tighra reservoir population as shown by allele richness, heterozygosity studies as well as pairwise $\mathrm{G}_{\mathrm{ST}}$ structure. RAPD-PCR markers analysis was able to characterize the genetic divergence between the lentic populations and could be helpful tools for defining better management strategies of $N$. notopterus. However, further analyses using co-dominant molecular markers like mt-DNA marker is recommended to making find out the exact genetic gene flow diversity among and between the $N$. notopterus populations.
\end{abstract}

\section{INTRODUCTION}

The conservation genetics or the application of genetics in the preservation of species has received increasing attention in last few decades. In the conservation biology, knowledge of the relatedness between populations is particularly important in captive breeding programs that seek to reduce incestuous mating in order to minimize inbreeding and the loss of genetic variations [1]. It is well known that, a decline in genetic variation reduces the ability of a population to adapt to environmental changes, therefore, decreases its long term survival [2]. Hence, loss of genetic diversity results in lower individual fitness and poor adaptability. Genetic diversity is a level of biodiversity that refers to the total number of genetic characteristics in the genetic makeup of a species. Advances in molecular biology techniques have provided the basis for uncovering virtually unlimited numbers of DNA markers. Clarification of taxonomic designations often needs to be addressed before appropriate conservation programs can be successfully implemented [3].

\section{* Corresponding Author}

Dr. R. K. Garg, Centre of Excellence in Biotechnology M.P. Council of Science and Technology (MPCST) Vigyan Bhawan, Nehru Nagar Bhopal-462003 (M.P.), India, Mob.: 09826220136; Tel.: 0755-2433124 E-mail: rkgargmpcst@gmail.com; rkgarg@mpcost.nic.in
Biological diversity has undergone restrictions due to direct and indirect anthropogenic activities. The reduction in the site of natural populations may have to reduction in evolutional options in the face of environmental changes due to loss of genetic diversity [4]. Most of the fishes used for human consumption are obtained from wild areas such as rivers, major lentic water bodies [5]. The management of the wild populations comprising commercial or sport fisheries presents genetic depletion that are unique to fisheries management and reduction of the genetic resources of natural fish populations has become an important fisheries management problem now a days [6]. India is blessed with a very rich and diverse natural water resource. The country is also endowed with a rich fish genetic biodiversity i.e., 2, 200 fish species and ranks $9^{\text {th }}$ in term of freshwater mega biodiversity [7]. 320 freshwater fishes assessed in India of which, 43 fish species were categorized as critically endangered (CE), 90 as endangered and 81 as vulnerable (VU), whereas, recent assessment for central India including Madhya Pradesh, Chattisgarh and Rajasthan reported 168 fish species of which, 41 species $(56.58 \%), 29(34.80 \%)$ and $18(11.16 \%)$ are placed as threatened under different categories [8] in Madhya Pradesh, Chattisgarh and Rajasthan respectively. Madhya Pradesh has rich fish fauna however, it declining faster than Chattisgarh and Rajasthan. 
Notopterus notopterus commonly known as "chamari menu" is widely distributed in ponds, pools, tanks and reservoirs of India. Notopterus notopterus is included in the sub-order Notopteridae under the order Osteoglassiforms and family Notopteridae. It is popular food fish for economically weaker communities due to low price and tasty flash. During CAMP [9], this fish was categorized as Lower Risk Near Threatened (LR-nt), whereas in CAFF [8] it was kept under endangered (EN). These reports clearly indicating that, fish going towards the extinction which may be due to over harvesting fish from reservoirs or may be due to high anthropogenic activities around the water bodies and may be due to threats. Therefore, present investigation has been taken to delineate the principles of fish population genetics, testing the basic assumptions for population genetic analysis, departures from Hardy-Weinberg expectation, linkage disequilibrium between the loci, estimation of the genetic differentiation within and among populations using genetic distance, FST and gene flow analyses, determination of frequencies of genes and genotypes and estimation of effective population sizes is to be find out to delineate the genetic diversity among and between the $N$. notopterus populations.

\section{MATERIALS AND METHODS}

\subsection{Study sites and samples collection}

Sampling sites were chosen to give a good representation of the distribution of this fish at Bhopal city and about more than 400 $\mathrm{km}$ away from Bhopal city i.e., Gwalior. 06 genotypes were caught from Upper Lake (Bhopal) lies between $23^{\circ} 12^{\prime}-23^{0} 16^{\prime} \mathrm{N}$ latitude and $77^{\circ} 18^{\prime}-77^{\circ} 23^{\prime} \mathrm{E}$ longitude, 05 genotypes from Lower Lake (Bhopal) and Tighra reservoir (Gwalior) lies between $23^{\circ} 14^{\prime}-23^{0}$ $16^{\prime} \mathrm{N}$ latitude, $77^{0} 24^{\prime}-77^{0} 25^{\prime} \mathrm{E}$ longitude and 26.0-12'-0" $\mathrm{N}$ latitude, 78-30-0 E longitude respectively (Fig. 2). All Individuals were chosen randomly and sampled directly from the reservoirs using cast net and with the help of local fishermen (Fig. 1). The specimens were kept in the iceboxes and brought to the laboratory, muscle and liver tissues were obtained and finally stored at $-80^{\circ} \mathrm{C}$.

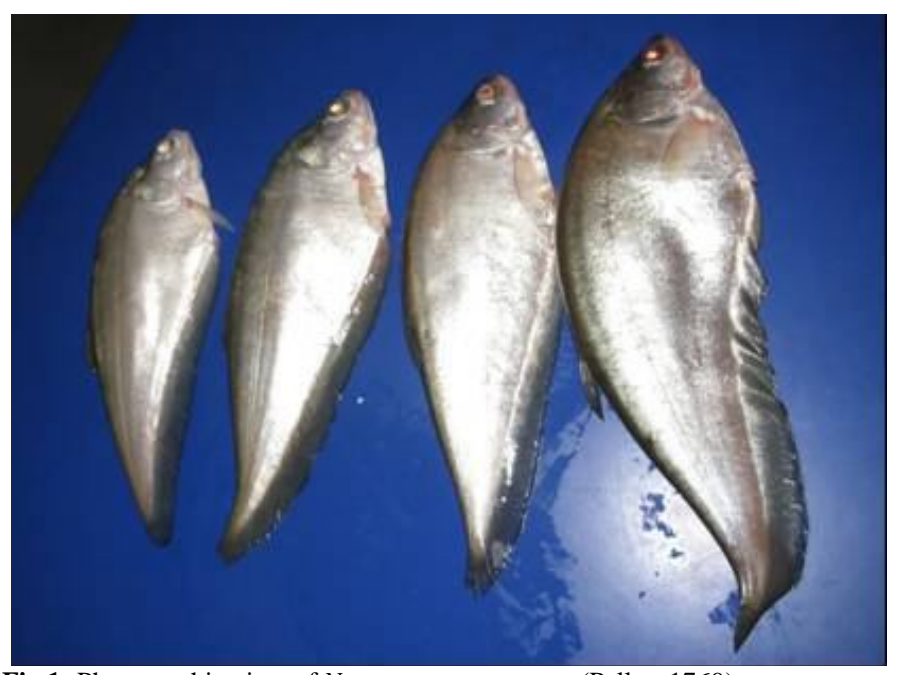

Fig.1: Photographic view of Notopterus notopterus (Pallas, 1769).

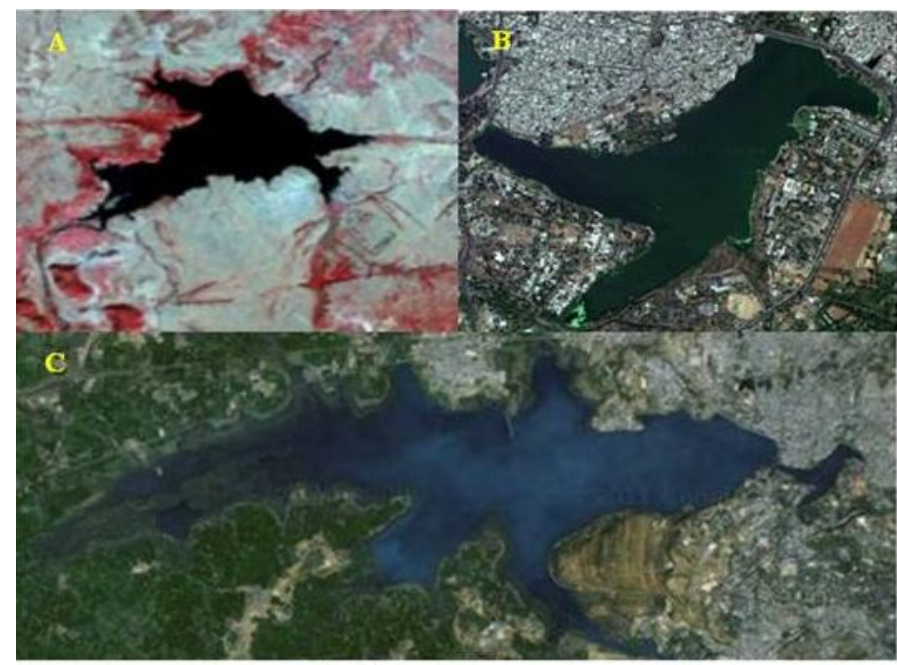

Fig. 2: Samples collection sites of Madhya Pradesh. (A) Tighra Reservoir, Gwalior; (B) Lower Lake, Bhopal; (C) Upper Lake, Bhopal

\subsubsection{Extraction of genomic DNA}

Total genomic DNA was extracted using phenol: chlorophorm: isoamyl (25:24:1) with some modifications [10, 11]. $100 \mathrm{mg}$ tissue sample was taken in pre-chilled eppendorf tube and the tissue was grinded. During grinding, $0.5 \mathrm{ml}$ of digestion buffer was added (100 mM Tris- $\mathrm{HCl}$ with $\mathrm{pH} 8.0,10 \mathrm{mM}$ EDTA, $1.4 \mathrm{M}$ $\mathrm{NaCl}, 1 \% \mathrm{SDS}$ and $0.2 \% \quad \beta$-Mercaptoethanol) in tubes and remaining $0.5 \mathrm{ml}$ was added after grinding. Sample was incubated at $50{ }^{0} \mathrm{C}$ for $30-60 \mathrm{~min}$ and then centrifuged at 5,000 rpm for 10 minutes at room temperature. Supernatant was collected in a fresh eppendorf tube and equal volume of phenol: chloroform: isoamylalcohol $(25: 24: 1)$ was added to the sample. Sample was again centrifuged at $10,000 \mathrm{rpm}$ for $10 \mathrm{~min}$ at $4{ }^{\circ} \mathrm{C}$ and transferred top aqueous layer to a new tube. Half volume of $7.5 \mathrm{M}$ ammonium acetate and 2 volumes of $100 \%$ chilled ethanol were added. The tube was kept in deep freezer for 1-2 hrs and centrifuged at 10,000 rpm for 10 minutes at $4{ }^{0} \mathrm{C} .1 \mathrm{ml}$ of $70 \%$ ethanol was added in the tube for washing and centrifuged for $10 \mathrm{~min}$ at $10,000 \mathrm{rpm}$ at $4{ }^{0} \mathrm{C}$. The upper aqueous layer is discarded and dried the pellet for 1-2 hrs at room temperature. $50 \mu \mathrm{l}$ Tris-EDTA buffers are added (10 $\mathrm{mM}$ Tris $\mathrm{HCl}, 1 \mathrm{mM}$ EDTA with $\mathrm{pH}$ 7.6) and stayed for 2 hours to dissolve the pellets. In the present study, ten commercially available oligonucleotide primers of Bangalore Genei, India were used to initiate PCR amplifications.

\subsubsection{Quantification of extracted genomic and visualization of DNA pattern}

The quantity and purity of DNA was determined spectrophotometrically (ND-1000, USA) PCR dilutions of 50 $\mathrm{ng} / \mu \mathrm{l}$ were used. Samples were treated by proteinase-K or RANase. The PCR reaction mixture $(25.50 \mu \mathrm{l})$ was composed of $12.50 \mu \mathrm{l}$ of Red Dye, $1.0 \mu \mathrm{l}$ primer, $11.00 \mu \mathrm{l}$ of sterile distilled water and $1.0 \mu \mathrm{l}$ template DNA. A negative control, without template DNA was also included in each round of reactions. The amplified pattern was visualized on an UV transilluminator and photographed by gel documentation system (Alpha-Innotech, 
USA) and after that scoring of the fingerprints and molecular weight was also performed by gel documentation system. The amplified DNA fragments were separated on $1.2 \%$ agarose gel and stained with ethidium bromide. A DNA ladder was run with each gel (100, 200,300, 600, 1000, 1500, 2000, 2500 and 3000 bp DNA ladder from Bangalore Genei, Bangalore, India). The amplified pattern was visualized and photographed by Gel Documentation System (Alpha-Innotech, USA).

\subsubsection{Data Analysis}

PCR amplified DNA fragments were scored for the presence (1) and absence ( 0 ) and arranged in the form of matrices for further evaluation. Observed number of alleles (na), effective number of alleles (ne), gene diversity (h), Shannon's Information Index (I), total number of loci and their percentage were estimated, moreover gene flow $\left(\mathrm{N}_{\mathrm{m}}\right)$, intra-population heterozygosity $\left(\mathrm{H}_{\mathrm{S}}\right)$, total heterozygosity $\left(\mathrm{H}_{\mathrm{T}}\right)$, relative differentiation $\left(\mathrm{G}_{\mathrm{ST}}\right)$, were also calculated to characterize the gene diversity and the distribution of the variation using a 'POPGENE' software package version 1.31 [12]. An unbiased measurement of genetic identity and genetic distance was calculated using [13]. The genetic diversity calculated as the ratio of the number of polymorphic RAPD markers found in a population over the total number of individuals sampled, and Weir's $D$ gene diversity. Relationships among the populations were estimated by way of un-weighted pair-group method (UPGMA) genetic distances, based on [14] standard genetic distance a neighbour joining $(\mathrm{NJ})$ tree was constructed using MEGA 5 software.

\section{RESULTS AND DISCUSSION}

In the present investigation, RAPD-PCR markers were used to anlysed genetic variability in 15 genotypes of Notopterus notopterus caught from three lentic water bodies such as Upper Lake and Lower Lake at Bhopal and Tighra reservoir at Gwalior representing north Madhya Pradesh. The geographic distance between Upper and Lower Lake of Bhopal and Tighra reservoir of Gwalior is more than $500 \mathrm{~km}$ (Fig. 2). RAn-01 (AM-765825), RAn-02 (AM-773324), RAn-03 (AM-765834), RAn-04 (AM750059), RAn-05 (AM-750052), RAn-06 (AM-765829), RAn-07 (AM-773781), RAn-08 (AM-765833), RAn-09 (AM-750057) and RAn-10 (AM-773782) primers were used and all were gave tremendous outcome to delineated genetic diversity in the three populations. Due to high polymorphism and variation in fragment intensities, many RAPD fragments could not be confidently compared between samples and between gels and were discarded from further analyses in the construction of the presence/absence matrix. RAPD markers have been found to have a wide range of application in gene mapping, population genetics, and molecular evolutionary genetics in plant and animal breeding system [15, $16]$.

PCR amplified DNA fingerprinting patterns obtained as 85 scorable loci in 16 genotypes of Notopterus notopterus representing three populations from Madhya Pradesh (representative images as Figs. 3-5). Maximum number of bands as 13 were produced by primer Ran-10 in genotypes of Upper Lake of which $100 \%$ were polymporphic, whereas, less number of polymporphism (50\%) showed by primer RAn-01. In Lower Lake primer RAn-01 produced highest number of bands as 10 and showed $100 \%$ polymorphism and primer RAn-10 showed less number of polymorphism with $66.66 \%$. In the Tighra reservoir, primers RAn-03 and RAn-06 showed highest percentage of polymorphism as $100 \%$ with giving 10 reproducible bands in the genotypes by each primer. The high molecular DNA fingerprints as 2972.22bp was obtained in genotypes of Tighra reservoir reproduced by RAn-02 (Table 1). $96.46 \%$ of polymorphism in Lower Lake was recorded, which is higher than C. catla $(75 \%)$, Oreochromis niloticus (55.76\%), Heterpneustes fossilis $(22.85 \%)$ studied by [17, 18, 19] showed a highest and significant differences in their degree of polymorphism as compared to our studies.

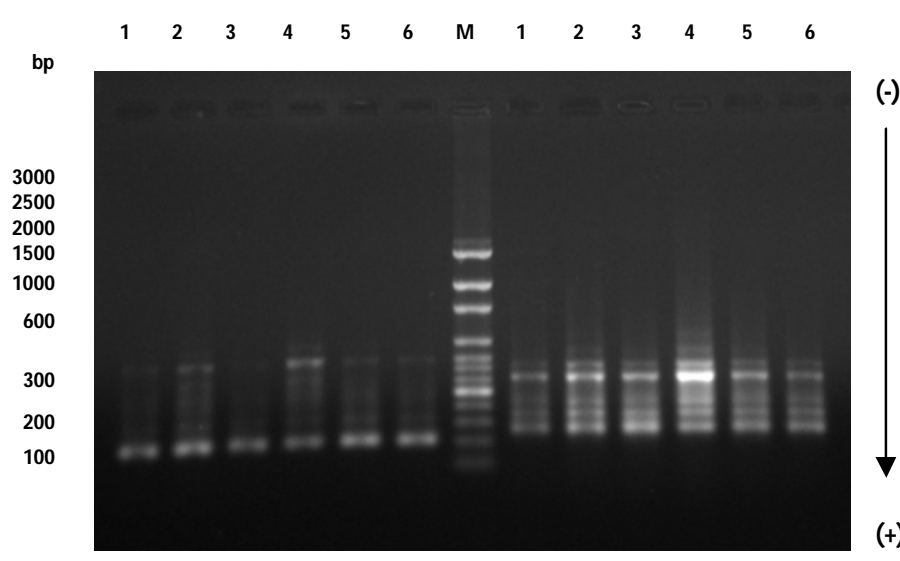

Fig. 3: DNA fingerprints in 06 individuals of $N$. notopterus of Upper La obtained by primer RAn- 04 \& RAn-5. 1-6 samples and M is molecular weis--. marker.

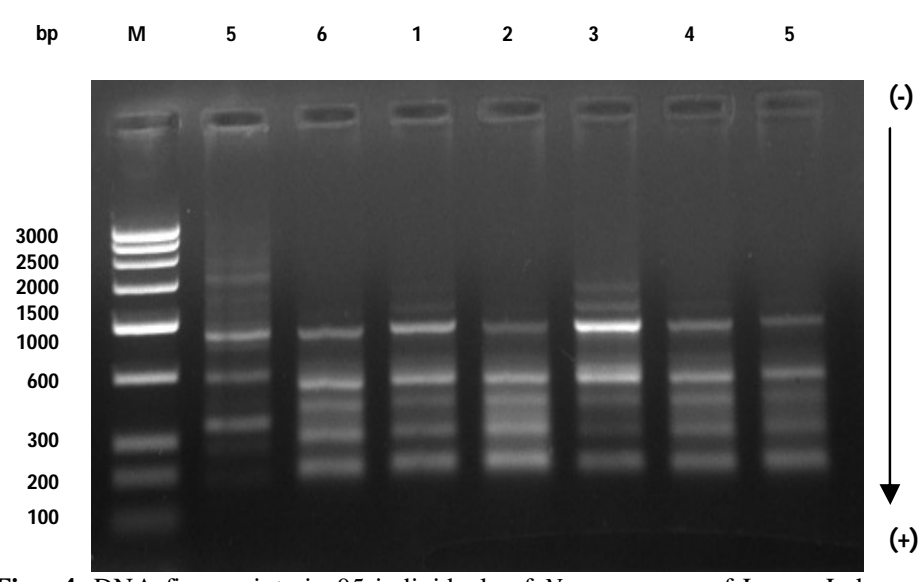

Fig. 4. DNA fingerprints in 05 individuals of $N$. notopterus of Lower Lake obtained by primer RAn- 01, RAn-03 \& RAn-04. 1-5 are samples for each primers \& $\mathrm{M}$ is molecular weight marker.

Gene flow can potentially reduces the genetic differentiation and be responsible for high within population variations [20, 21] which was observed in Ganga river on C. catla [22]. Overall proportion of estimated gene flow $(\mathrm{Nm})$ and relative 
differentiation (GST) across the primers studied in $N$. notopterus population were 1.6010 and 0.2380 respectively (Table 2). However, significant genetic differentiation was not detected in Chitala chitala on Ganga river [22]. Similarly, differentiation of haplotypes in L. rohita was significant for genetic structuring of 09 populations of 09 Indian rivers [23].

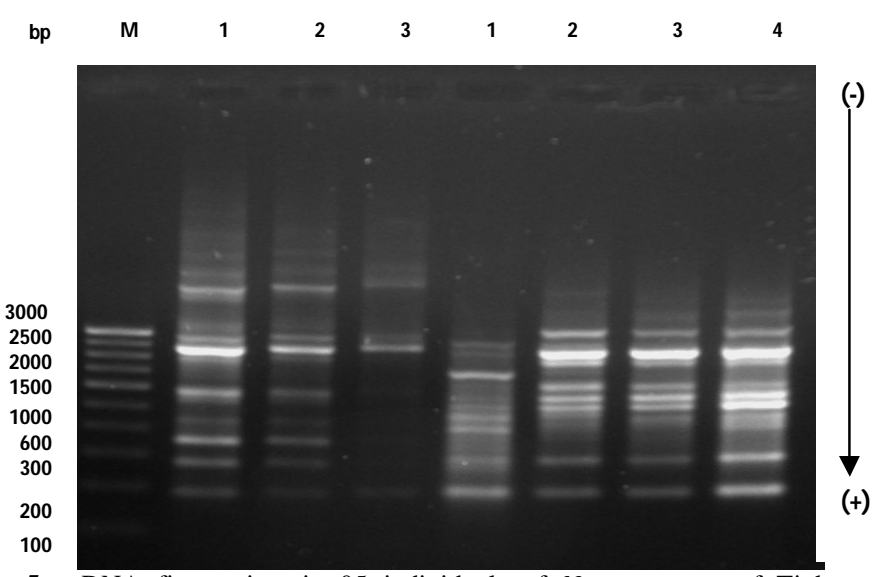

Fig. 5: DNA fingerprints in 05 individuals of $N$. notopterus of Tighra Reservoir obtained by primer RAn-09 (1-3), RAn-10 (1-4). M is molecular weight marker.

The success of conservation of an organism and effective management policies depend on the level of genetic divergence within and between species and developing strategies to maintain the natural genetic diversity [24]. Hence, the level of polymorphism/genetic divergence was as among Lower Lake fish genotypes, the proportion of polymorphic loci $(P)$ and gene diversity (Hpop) values were found to be high $(\mathrm{P}=96.47 \%, H \mathrm{pop}=$ $0.2464 \pm 0.1105)$ followed by the Upper Lake $(P=88.24 \%$, Hpop= $0.2602 \pm 0.1514)$ and Tighra reservoir $(P=72.94 \%$, Hpop $=$ $0.2305 \pm 0.1705$ ) genotypes ( Table 4 ). However, it indicates lowest percentage of polymorphic loci and less gene diversity Tighra reservoir, Gwalior. Relatively high level of genetic polymorphism (Table 4) in terms of the proportion of polymorphic loci, intrapopulation (Hs) indices $(0.2457 \pm 0.0069)$ and Nei's gene diversity in Lower Lake as compared to Upper Lake and Tighra reservoir was observed (Table 2). The overall total heterozygosity (HT) as $0.3225 \pm 0.0133$ was obtained in the genotypes of $N$. notopterus.
Random amplified polymorphic DNA markers noticeably depicted $N$. notopterus genotypes into their respective clusters based on their genetic divergence (Fig. 6) and gene flow which may also be concluded that, as compared to Upper lake and Lower lake genotypes, a genetic changes including reduced genetic diversity and significant differentiation have taken place in Tighra reservoir genotypes shown by allele richness, heterozygosity studies as well as pairwise GST structure.

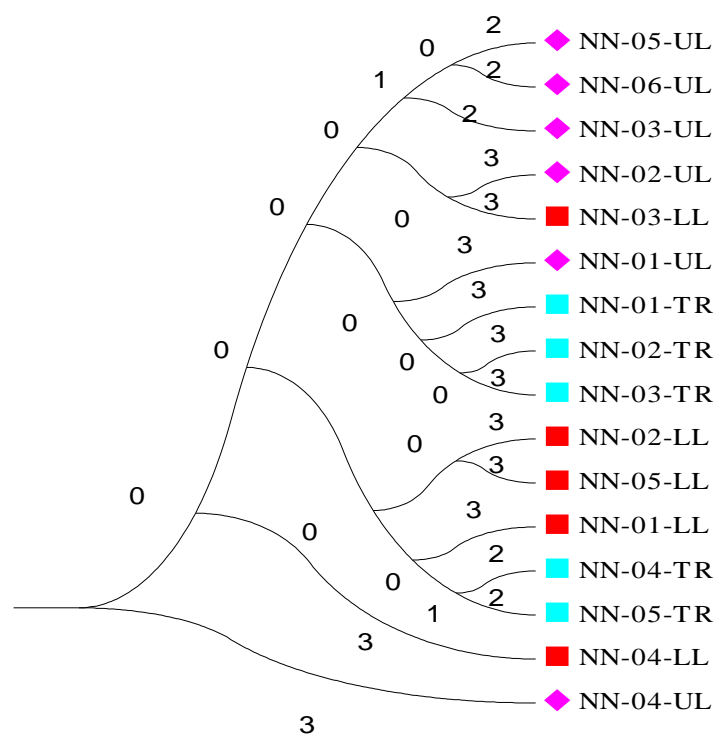

Fig. 6: Un-weighted pair group method with averages (UPGMA) phylogenetic relationship based on Nei's (1972) genetic distance $(D)$ among genotypes of $N$. notopterus constructed by Mega 5 software.

Genetic differentiation among the Tighra reservoir strains could reflect genetic drift due to intensive breeding practices. Thus, in the interests of optimal resource management, genetic variation should be monitored and in-breeding controlled within stocks in commercial breeding programs. Information on genetic population structure based on cross-species markers can aid in the proper management of $N$. notopterus populations. However, further analyses using co-dominant molecular markers like mt-DNA and microsatellite markers is recommended to making find out the exact genetic gene flow diversity among and between the Notopterus notopterus populations.

Table. 1: Pattern of polymorphism (primer wise) obtained by 10 RAPD primers in 16 genotypes from Upper Lake, Lower Lake \& Tighra reservoir.

\begin{tabular}{|c|c|c|c|c|c|c|c|c|c|c|c|c|}
\hline \multicolumn{5}{|c|}{ Upper Lake, Bhopal (n=06) } & \multicolumn{4}{|c|}{ Lower Lake, Bhopal (n=05) } & \multicolumn{4}{|c|}{ Tighra Reservoir, Gwalior $(\mathrm{n}=05)$} \\
\hline 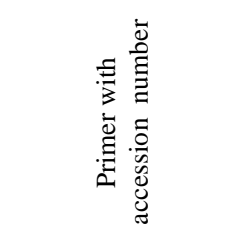 & 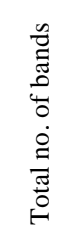 & 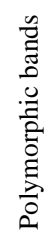 & 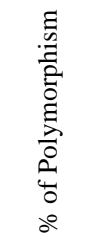 & 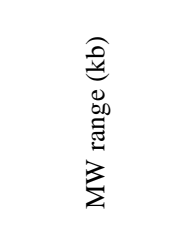 & 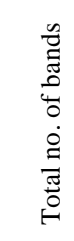 & 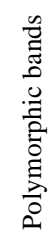 & 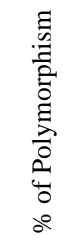 & 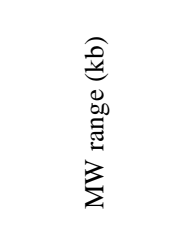 & 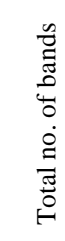 & 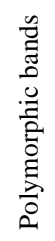 & 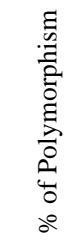 & 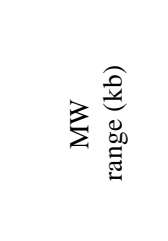 \\
\hline RAn-01(AM-765825) & 08 & 04 & 50.00 & $200.00-750.00$ & 10 & 10 & 100.0 & $254.55-1294.12$ & 13 & 12 & 92.30 & $150.00-2750.00$ \\
\hline RAn-02(AM-773324) & 08 & 06 & 75.00 & $161.11-1541.67$ & 06 & 05 & 83.33 & $400.00-1500.00$ & 10 & 09 & 90.00 & $272.73-2972.22$ \\
\hline RAn-03(AM-765834) & 10 & 10 & 100.0 & $153.65-1147.05$ & 07 & 07 & 100.0 & $300.00-1264.71$ & 10 & 10 & 100.0 & $218.18-2805.55$ \\
\hline RAn-04(AM-750059) & 06 & 06 & 100.0 & $163.64-771.43$ & 07 & 06 & 85.71 & $263.64-1029.41$ & 12 & 09 & 75.00 & $164.29-2727.27$ \\
\hline RAn-05(AM-750052) & 09 & 07 & 77.77 & $260.00-700.00$ & 07 & 06 & 85.71 & $209.09-1062.50$ & 10 & 10 & 100.0 & $142.86-2863.64$ \\
\hline RAn-06(AM-765829) & 11 & 11 & 100.0 & $200.00-1189.66$ & 10 & 09 & 90.00 & $107.14-1343.75$ & 09 & 09 & 100.0 & $500.00-2954.55$ \\
\hline RAn-07(AM-773781) & 09 & 06 & 66.66 & $111.11-1625.00$ & 06 & 05 & 83.33 & $190.00-900.00$ & 10 & 08 & 80.00 & $110.00-2812.50$ \\
\hline RAn-08(AM-765833) & 08 & 07 & 87.50 & $265.00-954.29$ & 07 & 06 & 85.71 & $263.64-1093.75$ & 13 & 11 & 84.61 & $100.00-2937.50$ \\
\hline RAn-09(AM-750057) & 09 & 09 & 100.0 & $220.00-1625.00$ & 05 & 04 & 80.00 & $190.00-860.00$ & - & - & - & - \\
\hline RAn-10(AM-773782) & 13 & 13 & 100.0 & 205.38-1923.69 & 09 & 06 & 66.66 & $238.42-1560.20$ & - & - & - & - \\
\hline
\end{tabular}


Table. 2: Overall Nei's (1987) analysis of gene diversity in subdivided populations of $N$. notopterus populations.

\begin{tabular}{lll}
\hline & Population Genetic Parameters & Obtained values \\
\hline Intra-population $\left(\mathrm{H}_{\mathrm{S}}\right)$ & & $0.2457 \pm 0.0069$ \\
Total heterozygosity $\left(\mathrm{H}_{\mathrm{T}}\right)$ & $0.3225 \pm 0.0133$ \\
Relative differentiation $\left(\mathrm{G}_{\mathrm{ST}}\right)$ & 0.2380 \\
Estimated gene flow $\left(\mathrm{N}_{\mathrm{m}}\right)$ & 1.6010 \\
\hline
\end{tabular}

Table. 3: Nei's (1978) unbiased measure of genetic identity and genetic distance among $N$. notopterus populations.

\begin{tabular}{lccc}
\hline \multicolumn{1}{c}{ Population name } & Upper Lake, Bhopal & Lower Lake, Bhopal & Tighra Reservoir, Gwalior \\
\hline Upper Lake, Bhopal $(\mathrm{n}=06$ & $* *$ & 0.8559 & 0.8644 \\
Lower Lake, Bhopal $(\mathrm{n}=05)$ & 0.1556 & $* *$ & 0.9108 \\
Tighra Reservoir, Gwalior $(\mathrm{n}=05)$ & 0.1458 & 0.0935 & $* *$ \\
\hline
\end{tabular}

Note: Nei's genetic identity (above diagonal) and genetic distance (below diagonal)

Table. 4: Gene Frequency, gene diversity and genetic polymorphism of 03 populations of N. notopterus at Single Population Level (SPL).

\begin{tabular}{|c|c|c|c|c|c|c|c|c|c|c|}
\hline \multirow[b]{2}{*}{ S. No. } & \multirow[b]{2}{*}{ Parameters } & \multicolumn{3}{|c|}{ Upper Lake (n=06) } & \multicolumn{3}{|c|}{ Lower Lake $(\mathrm{n}=05)$} & \multicolumn{3}{|c|}{ Tighra Reservoir (05) } \\
\hline & & $\begin{array}{c}\text { Range of } \\
\text { Variation }\end{array}$ & Mean & $\begin{array}{l}\text { Standard } \\
\text { Deviation }\end{array}$ & $\begin{array}{l}\text { Range of } \\
\text { Variation }\end{array}$ & Mean & $\begin{array}{l}\text { Standard } \\
\text { Deviation }\end{array}$ & $\begin{array}{c}\text { Range of } \\
\text { Variation }\end{array}$ & Mean & $\begin{array}{l}\text { Standard } \\
\text { Deviation }\end{array}$ \\
\hline 1. & Sample Size & 06 & 06 & - & 05 & 05 & - & 05 & 05 & - \\
\hline 2. & Observed number of alleles (na) & $1.0-2.0$ & 1.8824 & 0.3241 & $1.0-2.0$ & 1.9647 & 0.1856 & $1.0-2.0$ & 1.7294 & 0.4469 \\
\hline 3. & Effective number of alleles (ne) & $1.0-1.9533$ & 1.4124 & 0.3067 & $1.0-1.9780$ & 1.3601 & 0.2324 & $1.0-1.8688$ & 1.3668 & 0.3127 \\
\hline 4. & Nei's (1973) gene diversity (Hрор) & $0.0-0.4880$ & 0.2602 & 0.1514 & $0.0-0.4944$ & 0.2464 & 0.1105 & $0.0-0.4944$ & 0.2305 & 0.1705 \\
\hline 5. & Shannon Information Index (I) & $0.0-0.6811$ & 0.4071 & 0.2041 & $0.0-0.6876$ & 0.4019 & 0.1408 & $0.0-0.6876$ & 0.3564 & 0.2452 \\
\hline 6. & Total number of loci & & 85 & & & 85 & & & 85 & \\
\hline 7. & Number of Polymorphic loci & & 75 & & & 82 & & & 62 & \\
\hline 8. & $\%$ of polymorphic loci $(P)$ & & $88.24 \%$ & & & $96.47 \%$ & & & $72.94 \%$ & \\
\hline
\end{tabular}

\section{ACKNOWLEDGEMENTS}

The financial support from the Government of Madhya Pradesh is highly appreciated. The authors wish to thank Prof. Pramod K. Verma, Director General, MPCST \& Scientific Advisor of Government of Madhya Pradesh for his help and encouragement during the work.

\section{REFERENCES}

1. Frankham R, Ballou JD \& Briscoe DA, Introduction of Conservation Genetics. Cambridge University Press, New York, 2002.

2. Arif IA, Khan HA. Molecular markers for biodiversity analysis of wildlife animals: a brief review. Anim Biod Conserv, 2009; 32: 9.

3. Veronica A, Brown A, Brooke J, Fordyce A, McCracken GF. Genetic analysis of populations of the threatened bat Pteropus mariannus. Conser Genet, 2011; 12: 933.

4. Artoni RF, Vicari MR, Almeida MC, Moreira-Filho O, Bertollo LAC. Karyotype diversity and fish conservation of southern field from South Brazil. Rev Fish Biol Fish. 2009; 19: 393.

5. Agostinho AA, Pelicice FM, Gomes LC. Dams and the fish fauna of the Neotropical region: impacts and management related to diversity and fisheries. Braz J Biol. 2008; 68: 1119.

6. Yilmaz C, Okumuu O. Fish population Genetics and Applications of Molecular Markers to Fisheries and Aquaculture: I-Basic Principles of Fish Population Genetics. Turk J Fish Aqu Sci, 2002; 2: 145.

7. Mittermeier RA, Mittermeier CG. Mega-diversity; Earth's Biologically Wealthiest Nation Cemex, mexico City, Mexico McAlister DE, Hamilton A I, Harvey B (Eds) Global freshwater biodiversity; striving for the integrity of freshwater ecosystem. Sea Wind, 1997; 11: 1.

8. CAFF. Conservation Assessment of Freshwater Fish Diversity for Central India held at CIEF, Bhopal on November, 25: 2006.

9. CAMP. Report of the workshop on "Conservation Assessment and Management Plan. Zoos Outreach Organization and National Bureau of Fish Genetic Resources, Lucknow, 1998: 156.

10. Janarthanan S, Vincent S. Practical Biotechnology, Methods and Protocols, University Press India, 2007; 13: 978-81-7371-582-2.

11. Garg RK, Sairkar P, Silawat N, Vijay N, Batav N, Mehrotra NN. Genetic Diversity between Two Populations of Heteropneustes fossilis (Bloch) Using RAPD Profile. Int J Zool Res, 2009; 5: 171.

12. Yeh FC, Boyle TJB, Ye YZ, Xiyan JM, Popegene ver. 1.31. Microsoft Window-based freeware for population genetics analysis. University of Alberta and Center for International Forestry Research, 1999.
13. Nei M. Estimation of average heterozygosity and genetic distance from a small number of individuals. Genet, 1978; 89: 583.

14. Nei M. Analysis of gene diversity in sub-divided populations. Proc Nat Acad USA, 12; 1973: 3321.

15. Bardakci F. Random Amplified Polymorphic DNA (RAPD) Markers, Turk J Biol, 2001; 25: 185.

16. Ertas HB, Seker E. Isolation of Listeria monocytogenes from Fish Intestines and RAPD analysis, Turk J Vet Anim Sci, 2005; 29: 1007.

17. Islam MS, Ahmed ASI, Azam MS, Alam MS. Genetic Analysis of Three River Populations of Catla catla (Hamilton) Using Randomly Amplified Polymorphic DNA Markers. Asian-Aust J Anim Sci, 2005; 18: 453.

18. Zaeem SYE, Ahmed MMM. Genetic differentiation between sex reversal and Normal of Full-Sib Nile Tilapia, Oreochromis niloticus Based on DNA Fingerprinting. Res J Fish Hydrol, 2006; 1: 1.

19. Garg RK, Sairkar P, Silawat N, Vijay N, Mehrotra NN. RAPD analysis for genetic diversity of two populations of Mystus vittatus (Bloch) of Madhya Pradesh, India. Afr J Biotech, 2009; 8: 4032.

20. Ferguson A, Taggart JB, Prodohl PA, McMeel O, Thompson C, Stone C, McGinnity P \& Hynes RA. The application of molecular markers to the study and conservation of fish populations with special reference to Salmo. J Fish Biol, 1995; 47: 103.

21. Das R, Mohindra V, Singh RK, Lal KK, Punia P, Masih P, Mishra RM \& Lakra WS Intrapopulation genetic diversity in wild Catla catla (Hamilton, 1822) populations. J Appl Ichthyol, 2012: 1.

22. Mandal A, Mohindra V, Singh RK, Punia P, Singh AK \& Lal KK. Mitochondiral DNA variation in natural populations of endangered India Feather-Back Fish Chitala chitala, Mol Biol Rep, 2012;39: 1765.

23. Luhariya RK, Lal KK, Singh RK, Mohindra V, Punia P, Chauhan UK, Gupta A, Lakra WS. Genetic divergence in wild population of Labeo rohita (Hamilton, 1822) from nine Indian rivers, analyzed through mtDNA cytochrome $b$ region. Mol Biol Rep, 2012; 39: 3659.

24. Lakra WS, Goswami M, Gopalakrishnan A. Molecular identification and phylogenetic relationships of seven Indian Sciaenids (Pisces: Perciformes, Sciaenidae) based on 16S r-RNA and cytochrome c oxidase subunit I mitochondrial genes. Mol Biol Rep, 2009; 36: 831.

\section{How to cite this article:}

Garg RK, Batav N and Singh RK. Genetic divergence and gene flow in three populations of Notopterus notopterus (Pallas, 1769), Madhya Pradesh. J App Biol Biotech, 2014; 2 (04): 033-037. 